\title{
LIQUIDITY, PROFITABILITY, TAX RATE AND BANKRUPTCY RISK IN COLOMBIAN SMES
}

\author{
Nelson A. Andrade-Valbuena \\ Master in Business Administration, Grupo Entorno Económico, Universidad EAN \\ e-mail: nandrade4923@universidadean.edu.co | Calle 79 \# 11-45 Bogotá-Colombia \\ Fabio Fernando Moscoso Duran \\ Ph.D. Grupo Entorno Económico, Universidad EAN \\ e-mail: ffmoscoso@universidadean.edu.co | Calle 79 \# 11-45 Bogotá-Colombia

\section{Carlos Salcedo-Perez} \\ Ph.D. Facultad de Administración, Finanzas y Ciencias Económicas, Universidad EAN \\ e-mail: casalcedo@universidadean.edu.co | Calle 115 \# 10-45 Apt 202 Bogotá-Colombia
}

\begin{abstract}
This article looks for statistical evidence for the correlation between liquidity, profitability, tax rates and bankruptcy risk for the period 2011 - 2016 between Small and Medium Enterprises in Bogota (Colombia). To do so, the authors conducted a quantitative, longitudinal research for which the Altman Z" Score index was used. Data from 2,084 enterprises belonging to 19 industries was collected. The relations between the variables were analyzed by the Pearson correlation coefficient. A significant positive correlation between the risk of failure and low levels of liquidity was evidenced in several industries. The results for the relation between the risk of bankruptcy and profitability were not conclusive, neither significant. Not enough statistical evidence that related rates of return or tax rates to risk of failure was found.
\end{abstract}

Key words: Bankruptcy risk; SMEs; Altman Z Score Index, Tax Rates; Profitability; Liquidity.

JEL Classification: G33; M21; R51.

\begin{abstract}
RESUMEN
Este artículo busca evidencia estadística para la correlación entre la liquidez, rentabilidad, tasas de impuesto y el riesgo de quiebra en pequeñas y medianas empresas en Colombia (en el período 2011-2016). Para hace esto, los autores desarrollan un estudio longitudinal cuantitativo usando el Altman Z' Score index. Datos de 2,084 empresas de 19 industrias fueron recolectados. Las relaciones entre las variables fueron analizadas usando coeficientes de correlación de Pearson. Se encontró una correlación positiva significativa entre liquidez y riesgo de quiebra consistentemente en varias de las industrias. Los resultados para la correlación entre rentabilidad y riesgo de quiebra no fueron concluyentes. Tampoco se obtuvo una evidencia significativa estadísticamente respecto al relación entre tasas de impuesto y riesgo de quiebra.
\end{abstract}

Palabras clave: riesgo de quiebra, SMEs, Altman Z Score index, tasas de impuestos, rentabilidad, liquidez 


\section{INTRODUCTION}

SME's play a key role in any nation, especially because of their social and economic impacts, as a consequence of their weight in any productive structure, whether national or regional. Different studies show distinctive and repetitive affirmations regarding disadvantages related to administrative and financial matters that use to be the reasons of entrepreneurial failure in such organizations, the main being liquidity problems, low profitability, and those arising from the external business environment such as high tax rates.

Regardless the number of researches about the topic, most of them have been based on surveys, which can be a good source of information, but they can also be based on assumptions that do not reflect the real financial or administrative situation of the enterprise.

Therefore, this research aims at finding statistical evidence that can back up or refuse such affirmations, using the Altman Z'EMS Score, which analyzes information from financial statements. Since such information shows a more precise picture of the organizational real situation compared to the information provided by surveys, thus, better showing the operational reality of enterprises, understanding that an early, pertinent and adequate alert of the main causes of organizational failure can result in preventive or corrective actions that bring less social and economic costs associated with bankruptcies.

Based on the results provided by the Altman Z'EMS Score index, the researchers looked for evidence related to the existence of a direct or inverse relation among the risk of financial bankruptcy and the tax rate, profitability and liquidity answering the following research questions:

For Bogotanian SMEs:

Is there any relation between the risk of bankruptcy and the tax rate?

Is there any relation between the risk of bankruptcy and the profitability?

Is there any relation between the risk of bankruptcy and the liquidity?

Answers to such questions are shown according to their corresponding CIIU (determined by the Departamento Administrativo Nacional de Estadísticas [DANE]). This will allow to find out the financial risk vulnerability of each group, regarding tax rates, profitability and liquidity.

The aim of this research is to contribute with knowledge about Bogotanian SME's bankruptcies, a phenomenon that up to date has not been researched enough, and the studies performed about it have been limited both in number and measuring methodologies. In addition, results of this research are useful for policy makers who could concentrate their efforts to build a proper scenario that leads to Bogotanian SME's growth and prosperity.

\section{LITERATURE AND HYPOTHESES}

Lack of liquidity, low profitability and high tax rates are usually mentioned as the main factors that cause bankruptcies in Bogotanian SMEs. Therefore, the research is proposed as follows: 


\subsection{Liquidity}

The level of liquidity is usually the main problem directly related with SMEs' bankruptcies, not only nationally (CCB, 2009, p.12; GEM, 2013, p.71), but also in other economies (Bilderbeek, J., \& Pompe, P. P. (2005); Zainudin, N. (2006); Lugovskaya, L. (2010); Yazdanfar, D. (2011). Therefore, the following hypothesis is proposed:

Hypothesis I: there is a negative relation between the risk of bankruptcy of SMEs and their liquidity levels.

The "liquidity" variable, measured by using the current ratio, aims at finding the capacity of an organization to fulfill its short-term financial liabilities. The current ratio formula is:

(1) Liquidity (Current ratio) $=($ Current assets $) /($ Current liabilities)

\subsection{Profitability}

Besides being linked to bankruptcies by the CCB (2009, p.12), authors such as (Uribe, R., Gaitán, M., \& Potes, M. (2009); Parra, J. (2011), mention profitability as one of the factors linked to bankruptcies in Colombian SMEs; (Cerquera G. y Ruiz M. (2014) mention such factor for the specific case of Bogota. Studies performed in other economies, (Bilderbeek J. y Pompe, P. (2005); Reddy, C. V. (2012); Simona, B. S. (2015); di Donato, F., y Nieddu, L. (2015) also link profitability and bankrupticies. Therefore, risk of bankruptcy can be linked to profitability, and the following hypothesis is proposed:

Hypothesis II: there is negative relation between the risk of bankruptcy in SMEs and their profitability.

The profitability variable was analyzed using the Return on equity.

(2) $\quad$ Return On Equity $=($ Net income $) /\left(\right.$ Shareholer ${ }^{\wedge}$ s equity $)$

\subsection{Tax rates}

Tax rates were the third factor linked to bankruptcies mentioned by the CCB (2009, p.12) study. This might happen because:

High interest rates force organizations to reduce their working capital, which could lead to liquidity problems, as evidence by authors like (Lugovskaya, L., (2010); Zainudin, N., (2006); Mokhova, N., \& Zinecker, M., (2013)) show. It is important to highlight that such relation might be possible, because according to Price Waterhouse Coopers (PWH) (2015), interest rates in Colombia are higher than the average in the rest of the world (75.4\% in Colombia versus $40.9 \%$ in the rest of the world), which could be directly related to bankruptcy risk in SMEs.

An incremental use (or abuse) of debt as a way to take advantage of tax benefits (Falcon Crack, T., and Roberts, H, 2015) could lead to a continuous accumulation of unsustainable financial obligations, which brings a higher risk of bankruptcy.

Consequently, the next hypothesis is proposed: 
Hypothesis III: there is a positive relation between tax rates and risk of bankruptcy in SMEs.

The tax rate variable was measured using account number 54 of the Colombian Unified Accounting (PUC) that includes income taxes calculated according to current Colombian regulations. In addition, taxes were related to the account "Earning before taxes" in order to find a relative approximation as follows:

(3) Tax rates $=($ income tax $) /($ earnings before taxes $)$

\section{METHODOLOGY}

This is a quantitative research since it aims to measure and establish financial risk characteristics of Bogotanian SMEs without deliberate manipulation of any underlying variable. It is also a longitudinal study since it applies a repetitive and reiterated analysis of financial statements of the same enterprises during the period 2011-2016, looking for changes through time.

\section{The Altman Z"'-Score EMS model was used for the following reasons:}

Prediction accuracy: Chen \& Shimerda (1981) indicate that the effective prediction rate for financial-based bankruptcy cases is over 90\%; for the ZETA Altman models, the rate has been over $96 \%$ for prediction periods of less than one year, and until $70 \%$ for prediction periods of five years (Altman, E., 2000, p. 24).

In contrast with traditional financial indicators, Z-Score avoids bias related to subjective analysis or wrong assumptions arising from such subjectivity, since interpretations and categorization of results are defined previously by the model.

The Altman Z"'-Score EMS model is an analytical tool adjusted for developing countries or emerging markets, allowing for the inclusion of commercial or service companies as well as companies whose shares could or could not be traded in the stock market (Altman E., 2000, p. 35), features not included in the previous Z or Z' Scores models.

Versatility: Z-Score models have been applied in different periods, industries and countries, being used under different variables, techniques, statistics, timeframes and sample designs, finding not significant differences among the results obtained (Sánchez M., Acevedo I., and Castillo A. 2012, p.6).

Financial statements 2011-2016 were obtained from the public database of Superintendencia de Sociedades, which, according to Article 88 of Law 222 issued in 1995 establishes the authority of the President of Colombia to (by means of the Superintendencia de Sociedades) inspect, surveil and control companies and other institutions that the law determines so (Montero, 2005). Therefore, the Superintendencia de Sociedades becomes the appropriate source to get such data in Colombia.

Financial statements consulted belong to small and medium size enterprises from Bogota, classified by their Total Assets, as established by Law 905 issued in 2004 by the Congress of Colombia. Micro enterprises were not taken into account for this study because they are considered informal (DANE, 2007) cited by Guataquí, J., García, A., \& Rodríguez, M. (2011, p.92) and because in many cases their labor works without the required legal contracts and salaries (Rodríguez A., 2012, p.51).

The database collected 80,592 financial statements, 65,332 of which contained 
information from small and medium enterprises. Financial statements from enterprises that reported an operational income of $\$ 0$ for the years 2009-2014 were removed from the sample in order to eliminate any bias in the indicators and ratios. Enterprises that reported their financial statements without interruption during the period 2009-2014 were included.

CIIU categories with 30 or less enterprises were not taken into consideration (it means that groups D, E, O, Q, R, and S did not meet the minimum number of enterprises required to be included in the analysis)

From 5,636 enterprises (from which 33,816 financial statements for six consecutive years 2009-2014 were collected) using the Yamane method for calculation (Yamane, 1967 ; p. 886), a sample of 2,084 enterprises was selected, as shown in Table 1.

Table 1. Size of samples and classification according to CIIU code

\begin{tabular}{|l|l|l|}
\hline CIIU & Population & Yamane method \\
\hline Agriculture, cattle, hunting, forestry and fishing & 243 & 151 \\
\hline Mining and quarrying & 39 & 39 \\
\hline Manufacturing & 1,058 & 290 \\
\hline Distribution of electricity, gas, steam and air conditioning & 7 & \\
\hline Distrib. water; water sewage, waste treatment & 8 & \\
\hline Construction & 397 & 199 \\
\hline Wholesale and retail trade; automotive and motorcycle repair & 1,927 & 331 \\
\hline Transportation and warehousing & 136 & 101 \\
\hline Accommodation and food services & 112 & 88 \\
\hline Information and communication & 255 & 156 \\
\hline Finance and insurance & 64 & 55 \\
\hline Real estate activities & 355 & 188 \\
\hline Professional, scientific, and technical services & 647 & 247 \\
\hline Administrative support services & 297 & 170 \\
\hline $\begin{array}{l}\text { Public and defense administration; social security plans of mandatory } \\
\text { membership }\end{array}$ & 2 & \\
\hline Education & 39 & 30 \\
\hline Health care and social assistance & 394 \\
\hline Arts, entertainment, and recreation & 16 & 39 \\
\hline Other services & 30 & \\
\hline & 5636 & \\
\hline
\end{tabular}

Source: the authors

Although the bankruptcy measuring method was designed for emerging economies and developing countries, variables X2, X3, and X4 have not a direct equivalence with the Colombian PUC (see Table 2); that is why they were adapted using measures included in the Colombian PUC, financial income statements, balance sheets and cash flow statements. 
The equation that defines the Altman Z"' Score, its variables and interpretation is:

(4) Z” ZMS $=6.56(\mathrm{X} 1)+3.26(\mathrm{X} 2)+6.72(\mathrm{X} 3)+1.05\left(\mathrm{X} 4{ }^{\prime}\right)+3.25$

Table 2. Shows a summary of the variables included

\begin{tabular}{|l|l|l|}
\hline Variable & Altman definition & Adjusted definition \\
\hline X1 & $\begin{array}{l}\text { (Current assets - current liabilities) /total } \\
\text { assets }\end{array}$ & (Current assets - Current liabilities) / Total assets \\
\hline X2 & Retained earnings/total assets & $\begin{array}{l}\text { (Previous years results [37] * + profits and loss [59] * Reserves } \\
{[33] \text { *)/ Total assets }}\end{array}$ \\
\hline X3 & $\begin{array}{l}\text { EBIT/total assets } \\
\text { (Operational income + Depreciation + Amortization) / Total } \\
\text { assets }\end{array}$ \\
\hline X4 & $\begin{array}{l}\text { Book value of equity / Book value of total } \\
\text { liabilities }\end{array}$ & Total equity / Total liabilities \\
\hline
\end{tabular}

Source: the authors based on Altman E. (2000)

Its interpretation is as follows:

Table 3. Interpretation of Altman Z''EMS- Score

\begin{tabular}{|l|l|}
\hline Z"Value EMS & Clasification \\
\hline Z"'>6,15 & Safety \\
\hline Z" $<4,46$ & Bankruptcy area \\
\hline $4,46>$ Z" $>6,15$ & Grey zone \\
\hline
\end{tabular}

Source: the authors based on Altman E. I. (2002)

Each sampling group was selected by alphabetically organizing the population from each CIIU, and then numerically selecting the first of them according to the calculation obtained with the use of the Yamame Method.

Normal distributions were assumed, and the Grubbs criteria (Grubs, 1950) was applied for outlying extreme observations with a significance level of $5 \%$. Enterprises that showed extreme values in their financial statements were not considered for the study, being replaced by other enterprises from the population, in order to complete the number calculated by the Yamame Method.

Linear regression was used to verify the hypotheses. This was done because of direct and inverse relations of the hypotheses, mainly because of how dots propagated in the scatter plot and negative values in the ordinate and abscissa axis respectively, which did not allow for potential, logarithmic or exponential regressions.

\section{RESULTS AND DISCUSSION}

The lower the Z Altman indicators the higher the bankruptcy risk. Thus, in the scattering plot the "financial sustainability" variable has been considered as an inverse interpretation of the Altman scales, stating that the higher the Altman Z indicator the lower the enterprise's sensibility to bankruptcy and therefore the higher its financial stability. 
Hypothesis I: there is a negative relation between the risk of bankruptcy of SMEs and their liquidity levels.

Figure 1. Scattered plot of the sample - Financial sustainability Vs. Liquidity.

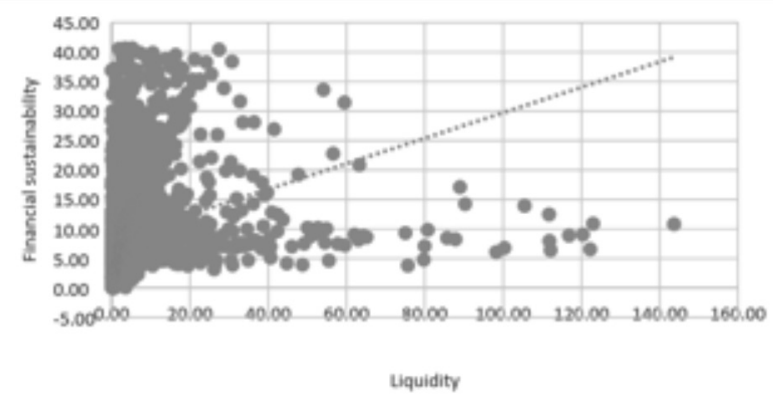

Source: the authors

The trend line in the scattered plot of Figure 1 shows a direct relation between liquidity and financial sustainability, so an analysis of estimation of parameters and the goodness-of-fit for the assumed hypothesis is performed (Table 4) as follows:

Table 4. Results of calculation of Pearson Correlation coefficient; critical P value; Coefficient of determination (R2) for the hypothesis Liquidity v/s Risk of bankruptcy.

\begin{tabular}{|c|c|c|c|c|c|c|c|c|c|}
\hline \multicolumn{10}{|c|}{ Liquidity } \\
\hline & $\mathrm{n}$ & & 2011 & 2012 & 2013 & 2014 & 2015 & 2016 & Average \\
\hline \multirow{3}{*}{ CIIU A } & \multirow{3}{*}{151} & $\mathrm{R}$ & 0,5222 & 0,248 & 0,250 & 0,109 & 0,197 & 0,149 & $24,6 \%$ \\
\hline & & P-Value & 0,000 & 0,002 & 0,002 & 0,182 & 0,016 & 0,068 & 0,045 \\
\hline & & $\mathrm{R}^{\wedge} 2$ & 0,273 & 0,062 & 0,063 & 0,012 & 0,039 & 0,022 & $7,8 \%$ \\
\hline \multirow{3}{*}{ CIIU B } & \multirow{3}{*}{39} & $\mathrm{R}$ & 0,7900 & 0,444 & 0,818 & 0,786 & 0,331 & 0,708 & $64,6 \%$ \\
\hline & & P-Value & 0,000 & 0,005 & 0,000 & 0,000 & 0,039 & 0,000 & 0,007 \\
\hline & & $\mathrm{R}^{\wedge} 2$ & 0,624 & 0,197 & 0,668 & 0,618 & 0,110 & 0,501 & $45,3 \%$ \\
\hline \multirow{3}{*}{ CIIU C } & \multirow{3}{*}{290} & $\mathrm{R}$ & 0,7033 & 0,708 & 0,753 & 0,862 & 0,669 & 0,609 & $71,7 \%$ \\
\hline & & P-Value & 0,000 & 0,000 & 0,000 & 0,000 & 0,000 & 0,000 & 0,000 \\
\hline & & $\mathrm{R}^{\wedge} 2$ & 0,495 & 0,501 & 0,567 & 0,742 & 0,447 & 0,371 & $52,1 \%$ \\
\hline \multirow{3}{*}{ CIIU F } & \multirow{3}{*}{199} & $\mathrm{R}$ & 0,4878 & 0,389 & 0,287 & 0,220 & 0,419 & 0,203 & $33,4 \%$ \\
\hline & & P-Value & 0,000 & 0,000 & 0,000 & 0,002 & 0,000 & 0,004 & 0,001 \\
\hline & & $\mathrm{R}^{\wedge} 2$ & 0,238 & 0,151 & 0,082 & 0,049 & 0,176 & 0,041 & $12,3 \%$ \\
\hline \multirow{3}{*}{ CIIU G } & \multirow{3}{*}{331} & $\mathrm{R}$ & 0,6219 & 0,360 & 0,397 & 0,721 & 0,874 & 0,701 & $61,3 \%$ \\
\hline & & P-Value & 0,000 & 0,000 & 0,000 & 0,000 & 0,000 & 0,000 & 0,000 \\
\hline & & $\mathrm{R}^{\wedge} 2$ & 0,387 & 0,130 & 0,158 & 0,520 & 0,764 & 0,491 & $40,8 \%$ \\
\hline
\end{tabular}




\begin{tabular}{|c|c|c|c|c|c|c|c|c|c|}
\hline \multicolumn{10}{|c|}{ Liquidity } \\
\hline & $\mathrm{n}$ & & 2011 & 2012 & 2013 & 2014 & 2015 & 2016 & Average \\
\hline \multirow{3}{*}{ CIIU H } & \multirow{3}{*}{101} & $\mathrm{R}$ & 0,2622 & 0,186 & 0,143 & 0,157 & 0,478 & 0,157 & $23,1 \%$ \\
\hline & & P-Value & 0,008 & 0,063 & 0,155 & 0,116 & 0,000 & 0,116 & 0,076 \\
\hline & & $\mathrm{R}^{\wedge} 2$ & 0,069 & 0,035 & 0,020 & 0,025 & 0,229 & 0,025 & $6,7 \%$ \\
\hline \multirow{3}{*}{ CIIU I } & \multirow{3}{*}{88} & $\mathrm{R}$ & 0,7384 & 0,815 & 0,782 & 0,709 & $-0,046$ & 0,649 & $60,8 \%$ \\
\hline & & P-Value & 0,000 & 0,000 & 0,000 & 0,000 & 0,671 & 0,000 & 0,112 \\
\hline & & $\mathrm{R}^{\wedge} 2$ & 0,545 & 0,664 & 0,611 & 0,503 & 0,002 & 0,421 & $45,8 \%$ \\
\hline \multirow{3}{*}{ CIIU J } & \multirow{3}{*}{156} & $\mathrm{R}$ & 0,6274 & 0,427 & 0,507 & 0,203 & 0,314 & 0,368 & $40,8 \%$ \\
\hline & & P-Value & 0,000 & 0,000 & 0,000 & 0,011 & 0,000 & 0,000 & 0,002 \\
\hline & & $\mathrm{R}^{\wedge} 2$ & 0,394 & 0,183 & 0,257 & 0,041 & 0,099 & 0,135 & $18,5 \%$ \\
\hline \multirow{3}{*}{ CIIU K } & \multirow{3}{*}{55} & $\mathrm{R}$ & 0,2725 & 0,763 & 0,202 & 0,375 & 0,681 & 0,735 & $50,5 \%$ \\
\hline & & P-Value & 0,044 & 0,000 & 0,140 & 0,005 & 0,000 & 0,000 & 0,031 \\
\hline & & $\mathrm{R}^{\wedge} 2$ & 0,074 & 0,582 & 0,041 & 0,141 & 0,464 & 0,541 & $30,7 \%$ \\
\hline \multirow{3}{*}{ CIIU L } & \multirow{3}{*}{188} & $\mathrm{R}$ & 0,1896 & 0,406 & 0,137 & 0,348 & 0,387 & 0,341 & $30,1 \%$ \\
\hline & & P-Value & 0,009 & 0,000 & 0,060 & 0,000 & 0,000 & 0,000 & 0,012 \\
\hline & & $\mathrm{R}^{\wedge} 2$ & 0,036 & 0,165 & 0,019 & 0,121 & 0,150 & 0,116 & $10,1 \%$ \\
\hline \multirow{3}{*}{ CIIU M } & \multirow{3}{*}{247} & $\mathrm{R}$ & 0,4183 & 0,833 & 0,170 & 0,850 & 0,728 & 0,653 & $60,9 \%$ \\
\hline & & P-Value & 0,000 & 0,000 & 0,007 & 0,000 & 0,000 & 0,000 & 0,001 \\
\hline & & $\mathrm{R}^{\wedge} 2$ & 0,175 & 0,694 & 0,029 & 0,723 & 0,531 & 0,427 & $43,0 \%$ \\
\hline \multirow{3}{*}{ CIIU N } & \multirow{3}{*}{170} & $\mathrm{R}$ & 0,4043 & 0,196 & 0,233 & 0,119 & 0,778 & 0,083 & $30,2 \%$ \\
\hline & & P-Value & 0,000 & 0,010 & 0,002 & 0,124 & 0,000 & 0,281 & 0,070 \\
\hline & & $\mathrm{R}^{\wedge} 2$ & 0,163 & 0,038 & 0,054 & 0,014 & 0,605 & 0,007 & $14,7 \%$ \\
\hline \multirow{3}{*}{ CIIU P } & \multirow{3}{*}{39} & $\mathrm{R}$ & 0,9431 & 0,848 & 0,723 & 0,698 & 0,661 & 0,400 & $71,2 \%$ \\
\hline & & P-Value & 0,000 & 0,000 & 0,000 & 0,000 & 0,000 & 0,011 & 0,002 \\
\hline & & $\mathrm{R}^{\wedge} 2$ & 0,889 & 0,720 & 0,523 & 0,487 & 0,436 & 0,160 & $53,6 \%$ \\
\hline \multirow{3}{*}{$\begin{array}{l}\text { YEARLY } \\
\text { AVERAGE }\end{array}$} & & $\mathrm{R}$ & 0,5370 & 0,509 & 0,416 & 0,474 & 0,498 & 0,443 & $47,9 \%$ \\
\hline & & P-Value & 0,005 & 0,006 & 0,028 & 0,034 & 0,056 & 0,037 & 0,028 \\
\hline & & $\mathrm{R}^{\wedge} 2$ & 0,336 & 0,317 & 0,238 & 0,307 & 0,312 & 0,251 & $29,3 \%$ \\
\hline
\end{tabular}

Source: the authors

As Table 4 shows, there is an evident average positive significant correlation $(r>0,505)$ for CIIU groups C, P, B, G, M, I and K, which suggest that liquidity and risk of bankruptcy are strongly related between these groups and change in the same direction. Besides, there is a significant $\mathrm{P}$-value $(\mathrm{P}$-Value $<0.05)$ in CIIU groups $\mathrm{C}, \mathrm{P}, \mathrm{B}$, $\mathrm{G}, \mathrm{M}, \mathrm{y} \mathrm{K}$, meaning that these results are not influenced by randomness and that the null hypothesis corresponding to Hypothesis I can be rejected. Even more, the average of determination coefficients is 0.422 , suggesting that the relation between liquidity and risk of bankruptcy explains about $44.2 \%$ of variations for these six groups.

Table 4 also shows a moderate correlation for enterprises that belong to CIIU group J ( $\mathrm{r}=40.8)$, meaning a good probability of relation between liquidity and risk of bankruptcy, although such relation is not too weak neither too strong to state conclusions regarding it. For all other CIIU groups there is a low positive correlation, meaning that even when both factors move along the same direction there is not a 
strong relation between liquidity and risk of bankruptcy, being unable to draw decisive conclusions about it.

All these indicates that there is sensibility to go into bankruptcy due to liquidity problems in enterprises belonging to the CIIU industries of manufacturing, mining and quarrying, trade, professional services, and financial services.

Regarding the evolution of the hypothesis proposed for the six consecutive years observed in the Annual Average of Table 4 (last row of said table). There is an evident decreasing trend in all three variables used for the analysis of estimation of parameters and the goodness-of-fit of the adjustment, so the explanation of the relation between liquidity and risk of bankruptcy becomes weaker through time. Mainly, in a significant positive correlation that goes from 0.537 in 2009 to 0.443 in 2014 and in the respective determination coefficients which suggest that the proposed hypothesis explained $33.6 \%$ of relations in 2009 and only $25.1 \%$ of variations in 2014; this means that as time goes by the relation between risk of bankruptcy and liquidity finds lower statistical support.

Such result generated a concern about the relation of the number of enterprises in risk of bankruptcy and the average lending interest rate in the market, since, as it was stated in the majority of researches consulted (including the 2009 study by the CCB), there was a direct relation between entrepreneurial failures and high interest rates. Figure 2 shows such relation.

Figure 2. Evolution of average lending rate and number of enterprises in bankruptcy zone.

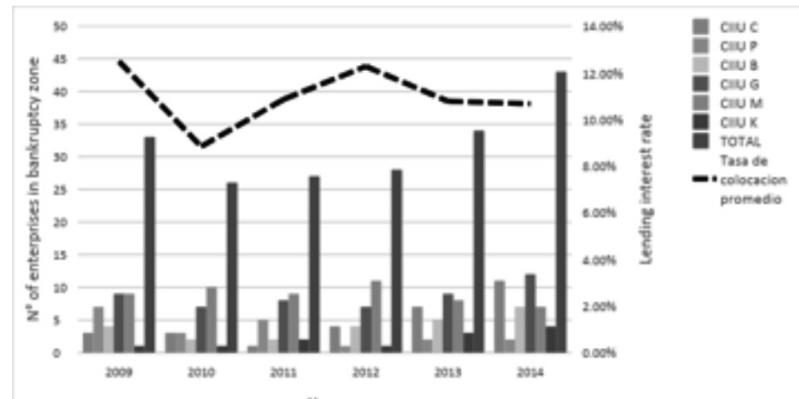

Source: the authors using data from Banco de la República (2015)

Therefore, a study of estimation of parameters and the goodness-of-fit of the proposed relation was performed, considering only those CIIU groups that evidenced susceptibility in the hypothesis Liquidity v/s risk of bankruptcy, as Table 5 shows: 
Table 5. Results of calculation of Pearson Correlation coefficient; critical P value; Coefficient of determination (R2) for the relation Average annual lending interest rate $\mathrm{v} / \mathrm{s}$ number of enterprises in bankruptcy zone.

\begin{tabular}{|l|c|c|c|}
\hline & $\mathrm{R}$ & $\mathrm{P}$-Value & $\mathrm{R}^{2}$ \\
\hline CIIU C & $-0,075$ & 0,885 & 0,006 \\
\hline CIIU P & 0,249 & 0,625 & 0,062 \\
\hline CIIU B & 0,272 & 0,592 & 0,074 \\
\hline CIIU G & 0,074 & 0,887 & 0,005 \\
\hline CIIU M & 0,135 & 0,794 & 0,018 \\
\hline CIIU K & $-0,177$ & 0,731 & 0,031 \\
\hline TOTAL & 0,143 & 0,782 & 0,020 \\
\hline
\end{tabular}

Source: the authors

As Table 5 shows, and according to the $\mathrm{R}$ coefficient that shows a low positive correlation of around $14 \%$ on average, it is possible to conclude that although both variables change in the same direction, it is not possible to infer the existence of a relation between them. This is confirmed by the $\mathrm{P}$ values, which are well above the reference value of 0.05 , indicating that the variance in the vertical axis (number of enterprises in bankruptcy zone) is inadequately explained by the relation with the average lending interest rate (abscissas). Even more, the R2 value indicates that only $2 \%$ of the variations is explained by the proposed hypothesis that relates the Average lending interest rate and the Number or enterprises in bankruptcy zone.

For hypothesis 1 , results show that there is a significant correlation between low liquidity levels and risk of bankruptcy for enterprises from manufacturing, education, mining and quarrying, trade, professional services, and financial services industries. As a matter of fact, low liquidity in such industries may be founded on other significant risky situations that generate such level of liquidity such as unsatisfactory or nonexistent financial policies, over debt, poor accounts receivable management, and low sales, among others.

Even though such variables were not directly analyzed in this research, its conclusions confirm liquidity as the most important risk factor for an enterprise's sustainability.

There was not an evident relation between low lending rates and the number of enterprises in bankruptcy zone. Regardless the former, results that support such conclusion do not take into account the easiness or difficulty encountered by organizations to access financial resources, since that is out of the scope of this research.

Hypothesis II: there is negative relation between the risk of bankruptcy in SMEs and their profitability. 
Figure 3. Scattered plot Financial sustainability v/s. Profitability.

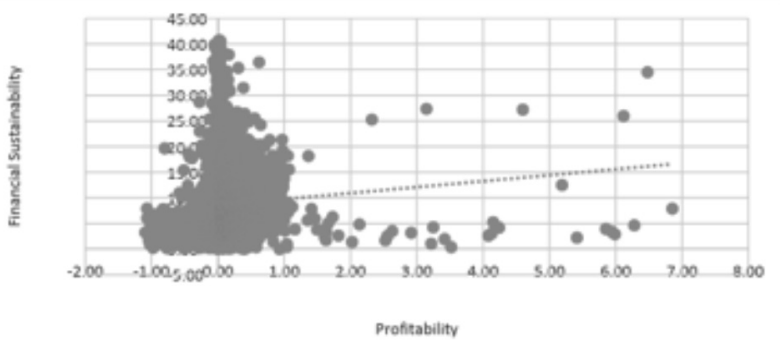

Source: the authors

There is evidence of a direct relation between Profitability and Financial sustainability, as shown by the trend line in the scattered plot in Figure 3. Therefore, the following estimation analysis was performed:

Table 6. Results of calculation of Pearson Correlation coefficient; critical P value; Coefficient of determination (R2) for the hypothesis Profitability v/s Risk of bankruptcy.

\begin{tabular}{|c|c|c|c|c|c|c|c|c|c|}
\hline \multicolumn{10}{|c|}{ ROE } \\
\hline & $\mathrm{n}$ & & 2011 & 2012 & 2013 & 2014 & 2015 & 2016 & Average \\
\hline \multirow{3}{*}{ CIIU A } & \multirow{3}{*}{151} & $\mathrm{R}$ & 0,0713 & 0,106 & 0,146 & 0,161 & $-0,105$ & 0,115 & $8,2 \%$ \\
\hline & & P-Valor & 0,385 & 0,194 & 0,074 & 0,048 & 0,197 & 0,161 & 0,176 \\
\hline & & $\mathrm{R}^{\wedge} 2$ & 0,005 & 0,011 & 0,021 & 0,026 & 0,011 & 0,013 & $1,5 \%$ \\
\hline \multirow{3}{*}{ CIIU B } & \multirow{3}{*}{39} & $\mathrm{R}$ & 0,3719 & 0,491 & 0,041 & 0,386 & 0,843 & $-0,152$ & $33,0 \%$ \\
\hline & & P-Valor & 0,019 & 0,001 & 0,806 & 0,015 & 0,000 & 0,355 & 0,199 \\
\hline & & $\mathrm{R}^{\wedge} 2$ & 0,138 & 0,241 & 0,002 & 0,149 & 0,710 & 0,023 & $21,1 \%$ \\
\hline \multirow{3}{*}{ CIIU C } & \multirow{3}{*}{290} & $\mathrm{R}$ & 0,3040 & 0,268 & 0,178 & 0,283 & 0,215 & $-0,053$ & $19,9 \%$ \\
\hline & & P-Valor & 0,000 & 0,000 & 0,002 & 0,000 & 0,000 & 0,365 & 0,061 \\
\hline & & $\mathrm{R}^{\wedge} 2$ & 0,092 & 0,072 & 0,032 & 0,080 & 0,046 & 0,003 & $5,4 \%$ \\
\hline \multirow{3}{*}{ CIIU F } & \multirow{3}{*}{199} & $\mathrm{R}$ & $-0,0758$ & $-0,030$ & 0,270 & 0,134 & 0,293 & 0,192 & $13,1 \%$ \\
\hline & & P-Valor & 0,287 & 0,676 & 0,000 & 0,059 & 0,000 & 0,007 & 0,171 \\
\hline & & $\mathrm{R}^{\wedge} 2$ & 0,006 & 0,001 & 0,073 & 0,018 & 0,086 & 0,037 & $3,7 \%$ \\
\hline \multirow{3}{*}{ CIIU G } & \multirow{3}{*}{331} & $\mathrm{R}$ & 0,1543 & $-0,029$ & 0,080 & 0,120 & $-0,420$ & 0,093 & $0,0 \%$ \\
\hline & & P-Valor & 0,005 & 0,594 & 0,144 & 0,029 & 0,000 & 0,093 & 0,144 \\
\hline & & $\mathrm{R}^{\wedge} 2$ & 0,024 & 0,001 & 0,006 & 0,014 & 0,176 & 0,009 & $3,8 \%$ \\
\hline \multirow{3}{*}{ CIIU H } & \multirow{3}{*}{101} & $\mathrm{R}$ & $-0,0330$ & 0,161 & 0,170 & $-0,319$ & $-0,579$ & $-0,408$ & $-16,8 \%$ \\
\hline & & P-Valor & 0,743 & 0,109 & 0,089 & 0,001 & 0,000 & 0,000 & 0,157 \\
\hline & & $\mathrm{R}^{\wedge} 2$ & 0,001 & 0,026 & 0,029 & 0,102 & 0,335 & 0,166 & $11,0 \%$ \\
\hline
\end{tabular}




\begin{tabular}{|c|c|c|c|c|c|c|c|c|c|}
\hline \multicolumn{10}{|c|}{ ROE } \\
\hline & $\mathrm{n}$ & & 2011 & 2012 & 2013 & 2014 & 2015 & 2016 & Average \\
\hline \multirow{3}{*}{ CIIU I } & \multirow{3}{*}{88} & $\mathrm{R}$ & $-0,1203$ & $-0,167$ & 0,085 & 0,184 & 0,196 & 0,130 & $5,1 \%$ \\
\hline & & P-Valor & 0,264 & 0,121 & 0,430 & 0,086 & 0,067 & 0,228 & 0,199 \\
\hline & & $\mathrm{R}^{\wedge} 2$ & 0,014 & 0,028 & 0,007 & 0,034 & 0,038 & 0,017 & $2,3 \%$ \\
\hline \multirow{3}{*}{ CIIU J } & \multirow{3}{*}{156} & $\mathrm{R}$ & 0,1184 & 0,071 & 0,264 & 0,132 & 0,514 & $-0,011$ & $18,2 \%$ \\
\hline & & P-Valor & 0,141 & 0,380 & 0,001 & 0,099 & 0,000 & 0,895 & 0,253 \\
\hline & & $\mathrm{R}^{\wedge} 2$ & 0,014 & 0,005 & 0,070 & 0,018 & 0,264 & 0,000 & $6,2 \%$ \\
\hline \multirow{3}{*}{ CIIU K } & \multirow{3}{*}{55} & $\mathrm{R}$ & $-0,0028$ & $-0,036$ & $-0,024$ & $-0,079$ & $-0,140$ & $-0,111$ & $-6,6 \%$ \\
\hline & & P-Valor & 0,984 & 0,794 & 0,859 & 0,565 & 0,306 & 0,420 & 0,655 \\
\hline & & $\mathrm{R}^{\wedge} 2$ & 0,000 & 0,001 & 0,001 & 0,006 & 0,020 & 0,012 & $0,7 \%$ \\
\hline \multirow{3}{*}{ CIIU L } & \multirow{3}{*}{188} & $\mathrm{R}$ & 0,0632 & $-0,024$ & 0,096 & $-0,045$ & 0,084 & $-0,032$ & $2,4 \%$ \\
\hline & & P-Valor & 0,389 & 0,742 & 0,189 & 0,543 & 0,250 & 0,662 & 0,462 \\
\hline & & $\mathrm{R}^{\wedge} 2$ & 0,004 & 0,001 & 0,009 & 0,002 & 0,007 & 0,001 & $0,4 \%$ \\
\hline \multirow{3}{*}{ CIIU M } & \multirow{3}{*}{247} & $\mathrm{R}$ & 0,1948 & 0,184 & 0,035 & 0,048 & $-0,021$ & 0,064 & $8,4 \%$ \\
\hline & & P-Valor & 0,002 & 0,004 & 0,583 & 0,451 & 0,747 & 0,318 & 0,351 \\
\hline & & $\mathrm{R}^{\wedge} 2$ & 0,038 & 0,034 & 0,001 & 0,002 & 0,000 & 0,004 & $1,3 \%$ \\
\hline \multirow{3}{*}{ CIIU N } & \multirow{3}{*}{170} & $\mathrm{R}$ & 0,2445 & $-0,272$ & 0,087 & 0,093 & 0,491 & $-0,070$ & $9,6 \%$ \\
\hline & & P-Valor & 0,001 & 0,000 & 0,259 & 0,229 & 0,000 & 0,366 & 0,143 \\
\hline & & $\mathrm{R}^{\wedge} 2$ & 0,060 & 0,074 & 0,008 & 0,009 & 0,241 & 0,005 & $6,6 \%$ \\
\hline \multirow{3}{*}{ CIIU P } & \multirow{3}{*}{39} & $\mathrm{R}$ & 0,0158 & 0,231 & 0,431 & $-0,109$ & 0,283 & $-0,569$ & $4,7 \%$ \\
\hline & & P-Valor & 0,924 & 0,157 & 0,006 & 0,508 & 0,081 & 0,000 & 0,279 \\
\hline & & $\mathrm{R}^{\wedge} 2$ & 0,000 & 0,053 & 0,186 & 0,012 & 0,080 & 0,323 & $10,9 \%$ \\
\hline \multirow{3}{*}{$\begin{array}{l}\text { YEARLY } \\
\text { AVERAGE }\end{array}$} & & $\mathrm{R}$ & 0,1005 & 0,073 & 0,143 & 0,076 & 0,127 & $-0,063$ & $7,6 \%$ \\
\hline & & P-Valor & 0,319 & 0,290 & 0,265 & 0,203 & 0,127 & 0,297 & 0,250 \\
\hline & & $\mathrm{R}^{\wedge} 2$ & 0,031 & 0,042 & 0,034 & 0,036 & 0,155 & 0,047 & $5,8 \%$ \\
\hline
\end{tabular}

Source: the authors

Results from Table 6 show a low positive correlation for CIIU C and CIIU B ( $r=0.19$ and $\mathrm{r}=0.33$ respectively), which suggest Profitability and Risk of bankruptcy are not strongly related, even as they move in the same direction. Besides, the $\mathrm{P}$ value 0.06 for CIIU $C$ is very close to the reference value ( $P$ value $<0.05)$, and having this research a considerably large sample $(n=296)$ this leads to believe that results are not influenced by randomness, and therefore the corresponding null hypothesis could be rejected. However, the results are not confirmed by variable R2; whose interpretation suggest that on average only $5.4 \%$ of variations are explained by the hypothesis proposed in such group of industries.

Additionally, there is a noticeable decreasing correlation of variables Profitability v/s Risk of bankruptcy for CIIU C group (0.3040 in 2009 decreasing to -0.053 in 2014) meaning that as time goes by the dependence between Risk of bankruptcy and Profitability for Bogotanian SME's shows less statistical evidence. For all three variables used for the analysis of estimation of parameters and the goodness-of-fit of the adjustments aligned among themselves, there is not enough statistical evidence 
to validate the hypothesis proposed for all the other industries.

Hypothesis III: there is a positive relation between tax rates and risk of bankruptcy in SMEs.

Figure 4. Scattered plot for Financial sustainability v/s Tax rate.

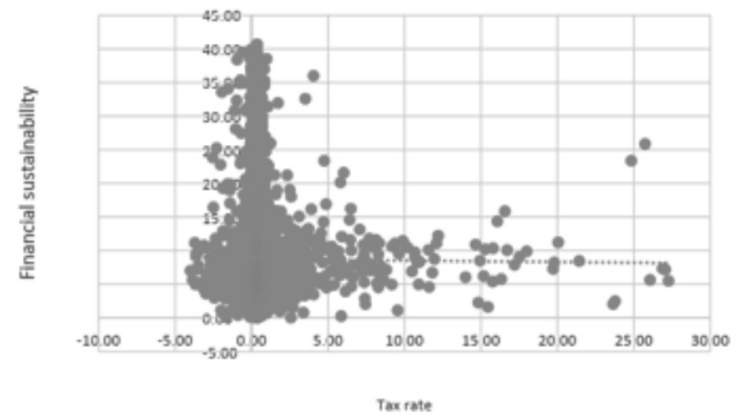

Source: the authors

There is evidence of an inverse relation between Tax rates and Financial sustainability, as shown by the trend line in the scattered plot in Figure 4. Therefore, the following analysis of estimation of parameters and goodness-of fit was performed:

Table 7. Results of calculation of Pearson Correlation coefficient; critical P value; Coefficient of determination (R2) for the hypothesis Tax rate v/s Risk of bankruptcy.

\begin{tabular}{|c|c|c|c|c|c|c|c|c|c|}
\hline \multicolumn{10}{|c|}{ Tax rate } \\
\hline & $\mathrm{n}$ & & 2011 & 2012 & 2013 & 2014 & 2015 & 2016 & Average \\
\hline \multirow{3}{*}{ CIIU A } & \multirow{3}{*}{151} & $\mathrm{R}$ & $-0,0021$ & $-0,001$ & 0,002 & $-0,063$ & $-0,029$ & 0,056 & $-0,6 \%$ \\
\hline & & P-Value & 0,980 & 0,992 & 0,979 & 0,444 & 0,726 & 0,494 & 0,769 \\
\hline & & $\mathrm{R}^{\wedge} 2$ & 0,000 & 0,000 & 0,000 & 0,004 & 0,001 & 0,003 & $0,1 \%$ \\
\hline \multirow{3}{*}{ CIIU B } & \multirow{3}{*}{39} & $\mathrm{R}$ & 0,2586 & 0,051 & $-0,193$ & 0,180 & $-0,038$ & 0,074 & $5,5 \%$ \\
\hline & & $P$-Value & 0,111 & 0,758 & 0,238 & 0,273 & 0,816 & 0,655 & 0,475 \\
\hline & & $\mathrm{R}^{\wedge} 2$ & 0,067 & 0,003 & 0,037 & 0,032 & 0,001 & 0,005 & $2,4 \%$ \\
\hline \multirow{3}{*}{ CIIU C } & \multirow{3}{*}{290} & $\mathrm{R}$ & 0,0224 & 0,018 & 0,059 & 0,061 & 0,247 & $-0,006$ & $6,7 \%$ \\
\hline & & P-Value & 0,704 & 0,761 & 0,317 & 0,302 & 0,000 & 0,918 & 0,500 \\
\hline & & $\mathrm{R}^{\wedge} 2$ & 0,001 & 0,000 & 0,003 & 0,004 & 0,061 & 0,000 & $1,2 \%$ \\
\hline \multirow{3}{*}{ CIIU F } & \multirow{3}{*}{199} & $\mathrm{R}$ & $-0,0343$ & $-0,166$ & $-0,118$ & $-0,116$ & 0,178 & $-0,136$ & $-6,5 \%$ \\
\hline & & P-Value & 0,631 & 0,019 & 0,098 & 0,104 & 0,012 & 0,055 & 0,153 \\
\hline & & $\mathrm{R}^{\wedge} 2$ & 0,001 & 0,027 & 0,014 & 0,013 & 0,032 & 0,019 & $1,8 \%$ \\
\hline
\end{tabular}




\begin{tabular}{|c|c|c|c|c|c|c|c|c|c|}
\hline \multicolumn{10}{|c|}{ Tax rate } \\
\hline & $\mathrm{n}$ & & 2011 & 2012 & 2013 & 2014 & 2015 & 2016 & Average \\
\hline \multirow{3}{*}{ CIIU G } & \multirow{3}{*}{331} & $\mathrm{R}$ & 0,0585 & 0,027 & $-0,049$ & 0,042 & $-0,010$ & 0,052 & $2,0 \%$ \\
\hline & & P-Value & 0,288 & 0,629 & 0,370 & 0,448 & 0,855 & 0,350 & 0,490 \\
\hline & & $\mathrm{R}^{\wedge} 2$ & 0,003 & 0,001 & 0,002 & 0,002 & 0,000 & 0,003 & $0,2 \%$ \\
\hline \multirow{3}{*}{ CIIU H } & \multirow{3}{*}{101} & $\mathrm{R}$ & 0,0785 & 0,041 & 0,384 & $-0,013$ & 0,068 & $-0,140$ & $7,0 \%$ \\
\hline & & P-Value & 0,435 & 0,687 & 0,000 & 0,898 & 0,500 & 0,163 & 0,447 \\
\hline & & $\mathrm{R}^{\wedge} 2$ & 0,006 & 0,002 & 0,148 & 0,000 & 0,005 & 0,020 & $3,0 \%$ \\
\hline \multirow{3}{*}{ CIIU I } & \multirow{3}{*}{88} & $\mathrm{R}$ & 0,0712 & 0,009 & $-0,077$ & $-0,136$ & $-0,310$ & 0,013 & $-7,2 \%$ \\
\hline & & P-Value & 0,509 & 0,935 & 0,475 & 0,206 & 0,003 & 0,902 & 0,505 \\
\hline & & $\mathrm{R}^{\wedge} 2$ & 0,005 & 0,000 & 0,006 & 0,019 & 0,096 & 0,000 & $2,1 \%$ \\
\hline \multirow{3}{*}{ CIIU J } & \multirow{3}{*}{156} & $\mathrm{R}$ & $-0,0251$ & $-0,074$ & 0,026 & 0,099 & 0,065 & 0,106 & $3,3 \%$ \\
\hline & & P-Value & 0,756 & 0,359 & 0,747 & 0,218 & 0,419 & 0,188 & 0,448 \\
\hline & & $\mathrm{R}^{\wedge} 2$ & 0,001 & 0,005 & 0,001 & 0,010 & 0,004 & 0,011 & $0,5 \%$ \\
\hline \multirow{3}{*}{ CIIU K } & \multirow{3}{*}{55} & $\mathrm{R}$ & $-0,1197$ & $-0,134$ & 0,012 & $-0,124$ & 0,012 & 0,146 & $-3,5 \%$ \\
\hline & & P-Value & 0,384 & 0,330 & 0,932 & 0,366 & 0,931 & 0,288 & 0,538 \\
\hline & & $\mathrm{R}^{\wedge} 2$ & 0,014 & 0,018 & 0,000 & 0,015 & 0,000 & 0,021 & $1,2 \%$ \\
\hline \multirow{3}{*}{ CIIU L } & \multirow{3}{*}{188} & $\mathrm{R}$ & 0,1569 & $-0,121$ & $-0,043$ & 0,072 & 0,030 & 0,237 & $5,5 \%$ \\
\hline & & P-Value & 0,031 & 0,098 & 0,559 & 0,325 & 0,687 & 0,001 & 0,284 \\
\hline & & $\mathrm{R}^{\wedge} 2$ & 0,025 & 0,015 & 0,002 & 0,005 & 0,001 & 0,056 & $1,7 \%$ \\
\hline \multirow{3}{*}{ CIIU M } & \multirow{3}{*}{247} & $\mathrm{R}$ & $-0,1104$ & $-0,129$ & $-0,047$ & $-0,096$ & $-0,020$ & $-0,030$ & $-7,2 \%$ \\
\hline & & P-Value & 0,083 & 0,042 & 0,466 & 0,133 & 0,753 & 0,635 & 0,352 \\
\hline & & $\mathrm{R}^{\wedge} 2$ & 0,012 & 0,017 & 0,002 & 0,009 & 0,000 & 0,001 & $0,7 \%$ \\
\hline \multirow{3}{*}{ CIIU N } & \multirow{3}{*}{170} & $\mathrm{R}$ & 0,0220 & 0,094 & $-0,025$ & 0,077 & $-0,126$ & 0,083 & $2,1 \%$ \\
\hline & & P-Value & 0,776 & 0,225 & 0,743 & 0,319 & 0,101 & 0,280 & 0,407 \\
\hline & & $\mathrm{R}^{\wedge} 2$ & 0,000 & 0,009 & 0,001 & 0,006 & 0,016 & 0,007 & $0,6 \%$ \\
\hline \multirow{3}{*}{ CIIU P } & \multirow{3}{*}{39} & $\mathrm{R}$ & $-0,1771$ & 0,101 & 0,202 & 0,131 & $-0,032$ & 0,007 & $3,9 \%$ \\
\hline & & P-Value & 0,280 & 0,542 & 0,217 & 0,425 & 0,844 & 0,965 & 0,545 \\
\hline & & $\mathrm{R}^{\wedge} 2$ & 0,031 & 0,010 & 0,041 & 0,017 & 0,001 & 0,000 & $1,7 \%$ \\
\hline \multirow{3}{*}{$\begin{array}{l}\text { YEARLY } \\
\text { AVERAGE }\end{array}$} & & $\mathrm{R}$ & 0,0153 & $-0,022$ & 0,010 & 0,009 & 0,003 & 0,036 & $0,8 \%$ \\
\hline & & $\mathrm{P}$-Value & 0,459 & 0,491 & 0,472 & 0,343 & 0,511 & 0,453 & 0,455 \\
\hline & & $\mathrm{R}^{\wedge} 2$ & 0,013 & 0,008 & 0,020 & 0,011 & 0,017 & 0,011 & $1,3 \%$ \\
\hline
\end{tabular}

Source: the authors

Results show an isolated and disperse presence of statistical data to support the hypothesis that relates Tax rates and Risk of bankruptcy for Bogotanian SMEs; therefore, there is not enough statistical evidence to reject the null hypothesis relating such variables. 


\section{CONCLUSION}

Out of the 2084 Bogotanian SMEs analyzed, it is possible to infer the following conclusions related to the proposed hypotheses:

For Hypothesis I: “there is a negative relation between SMEs' bankruptcy risk and their liquidity levels", there is statistical evidence to prove the relation between low liquidity and risk of bankruptcy for the following industries (being manufacturing the industry that evidenced the highest relation between both variables): Manufacturing, Education, Mining and quarrying, Trade, Professional services and Financial services.

A direct conclusion is that there is not a clear relation between lending interest rates and the number of enterprises in bankruptcy zone. Regardless, results do not take into consideration the easiness or difficulty enterprises face to access financial resources. However, liquidity risks in such industries may be founded on other significantly risky scenarios (that therefore generate low liquidity) such as unsatisfactory or nonexistent financial policies, over debt, poor accounts receivable management, low sales levels among others; although such scenarios were not analyzed directly in this research, conclusions of this study confirm liquidity as the most important risk factor for the sustainability of an enterprise.

For Hypothesis II: "there is negative relation between the risk of bankruptcy in a SME and its profitability", findings were not conclusive, neither significant. Overall, based on the analysis of financial statements, there was not enough evidence to be able to conclude that low profitability rates determine the risk of bankruptcy of enterprises. An explanation might be found for the case of SMEs that develop important levels of production using economies of scale, which in turn will determine their growth by the number of units sold (increasing marginal returns). Thus, it is not possible to establish an optimal level of profitability for Bogotanian SMEs, neither that the inherent risk of a possible bankruptcy depends on their profitability.

Regarding Hypothesis III, "there is a positive relation between tax rates and risk of bankruptcy in SMEs", according to Comision Economica para America Latina y El Caribe (2012), Colombia is one of the Latin American countries where enterprises pay higher taxes; Colombia ranks fourth in terms of collection from taxes on equity as percentage of GDP. However, this study showed not strong statistical support regarding a relation between tax rates and risk of bankruptcy for the case of Bogotanian SMEs; therefore, for such enterprises, it is not possible to conclude that there is an increase in the bankruptcy as result of high tax rates.

Limitations of the study and the main findings referring to the relation between low liquidity and risk of bankruptcy in certain Bogotanian industries, are a motivation for further research on the topic -due to its relevance and lack of studies about it-, not only by the academic community, but also by other groups mentioned in the introduction of this article, given the topic's importance.

\section{REFERENCES}

Altman, E. I. (2000). Predicting financial distress of companies: revisiting the Z-score and ZETA models. Stern School of Business, New York University, 9-12. 
Altman, E. I. (2002). Corporate distress prediction models in a turbulent economic and Basel II environment. [Online]. Social Science Research Network, September 2002 [Retrieved on: September 30, 2014].

Banco De La República (2014). Salario mínimo legal en Colombia. [Online] Bogotá: Banco de la Republica, December 2014 [Retrieved on: May 11, 2015]. Retrieved from: <http://goo.gl/5kbpcW>

Banco De La República (2015). Tasas de colocación consolidadas Promedio Mensual. [Online] Bogotá: Banco de la Republica, April 2015.

Bilderbeek, J., \& Pompe, P. P. (2005). The Prediction of Bankruptcy of Small-and Medium-Sized Industrial Firms. Journal of Business Venturing, 20(6), 847-868. http://dx.doi.org/10.1016/j.jbusvent.2004.07.003

CCB [Cámara de Comercio de Bogotá] (2014). Dinámica económica y empresarial 2013 y perspectivas 2014 Bogotá: CCB. No. 22. June 2014. ISSN: 2248-4515

Cerquera G. y Ruiz M. (2014). Identificación de los factores de quiebra en las pymes de la localidad de Puente Aranda de Bogotá. Comité científico, 50.

Chen, K., y Shimerda, T. (1981). An empirical analysis of useful financial ratios. Financial Management, 51-60. http://dx.doi.org/10.2307/3665113

Díaz Z., Fernández J., y Segovia M. (2004). Sistemas de inducción de reglas y árboles de decisión aplicados a la predicción de insolvencias en empresas aseguradoras. [Online] Madrid: Universidad Complutense de Madrid, May 2014

di Donato, F., y Nieddu, L. (2015). The Effects of Performance Ratios in Predicting Corporate Bankruptcy: The Italian Case. In Decision Support Systems V-Big Data Analytics for Decision Making (pp. 61-72). Springer International Publishing. http:// dx.doi.org/10.1007/978-3-319-18533-0_6

Falcon Crack, T., \& Roberts, H. (2015). Credit Cards, Excess Debt, and the Time Value of Money. Journal of Financial Education, 41(1).

GEM [Global Entrepreneurship Monitor] (2013). GEM: Reporte anual Bogotá 2012-2013 [Online] Bogotá: Uniandes, May 2014.

Grubbs, F. (1950). Sample criteria for testing outlying observations, The Annals of Mathematical Statistics 21(1), p.27-58, DOI: 10.1214/aoms/1177729885, March 1950.

Guataquí, J., García, A., \& Rodríguez, M. (2011). El perfil de la informalidad laboral en Colombia. Perfil de coyuntura económica, (16), 91-115. [Online] Medellin: Universidad de Antioquia, August 2014.

Lugovskaya, L. (2010). Predicting default of Russian SMEs on the basis of financial and non-financial variables. Journal of Financial Services Marketing, 14(4), 301-313. 
http://dx.doi.org/10.1057/fsm.2009.28

Montero, J. (2005). Régimen societario colombiano. En: Estudio del Régimen Legal Colombiano, 1era ed. Bogotá: Bancoldex - Secretaría General, p.5.

Pachulia, G. y Henderson, L. (2009). The relationship between emotional intelligence and entrepreneurial orientation; observed within owner managers who lead small, high tech firms in Sweden. Master Thesis not yet published, Jönköping University, Jönköping.

Parra, J. (2011). Probability determinants of new enterprises closure in Bogotá. Revista Facultad de Ciencias Económicas: Investigación y Reflexión, 27-53.

PWH [Price Waterhouse Coopers] (2015). Paying taxes 2015. [Online] PWC, May 2015 Reddy, C. V. (2012). Analysis of Liquidity, Profitability, Risk and Financial Distress: A Case Study of Dr. Reddy's Labs. Indian Journal of Finance, 6(12), 5-17.

Rodríguez, A. A. S. (2012). Famiempresa, simbiosis organizacional: una perspectiva de desarrollo, derechos y género. Tendencias \& Retos, 17(2), 49-62.

Sánchez M., Acevedo I., Castillo A. (2012) Análisis económico-financiero de los modelos de predicción de quiebra y la probabilidad de quiebra. [Online] México: U. Autónoma de Hidalgo, September 2014.

Simona, B. S. (2015). Analysis Models of Bankruptcy Risk. Ovidius University Annals, Series Economic Sciences, 15(1).

Uribe, R., Gaitán, M., \& Potes, M. (2009). Pymes Colombia. Revista EAN 77-106.

Yamane, T. (1967). Elementary Sampling Theory Prentice. Englewood C. NS, USA.

Yazdanfar, D. (2011). Predicting bankruptcy among SMEs: evidence from Swedish firm-level data. International Journal of Entrepreneurship and Small Business, 14(4), 551-565. http://dx.doi.org/10.1504/IJESB.2011.043475

Zainudin, N. (2006). Liquidity-profitability trade-off: is it evident among Malaysian SMEs?. International Journal of Management Studies, 13(2), 107-118. 